\title{
Road Tax on Truck Traffic with Environmental Aspects
}

\author{
Břetislav Andrlik*
}

\section{Introduction}

In the Czech Republic, road tax is included into the category of property taxes, although the OECD classification considers it as an excise tax. Accordingly, specialized literature does not always regard the road tax as a typical property tax. Boněk (2001) mentions, that despite the above aspects, road tax is included within property taxes because it approximates property taxes in certain features, particularly the tax method used. From the theoretical viewpoint, road tax is best defined by the benefit principle, which is part of the principle of fair taxation comprising the benefit principle and the ability-to-pay approach. In relation to tax liabilities, this principle may be defined in such manner that individual tax liabilities should be derived solely from the benefit gained from the consumption of public goods. Arguments supporting this principle in relation to road tax have their origin in Locke's theory of social contract dating back to the end of the 17th century, where the state is considered the protector and guardian of all the property. Assuming this position we may clearly derive that the property owners must contribute to the state expenditure so that the state may ensure this basic function. In this context, the road tax revenue should serve to finance the state expenses connected with maintenance, renovation, repair and construction of road infrastructure in a particular country. The interpretation of this principle is also based on the proposition that higher taxes should be paid by those who most benefit from such services, and vice versa. The question is which individuals benefit most from the state services, and here we can ascertain two perspectives. According to one, the amount of tax liability should depend on the amount of income. The other says that wealthy individuals are able to procure many services at their own account, and therefore poorer people benefit more from services

Ing. Břetislav Andrlík, Ph.D. - Research Assistant; Department of Accounting and Taxes, Faculty of Business and Economics, Mendel University in Brno, Zemědělská 1, 61300 Brno, <bretislav.andrlik@ mendelu.cz>. 
provided by the state. The benefit principle is used with those state services where it can be applied. In relation to taxation of motor vehicle traffic, this principle may be identified according to David (2012) also in the case of tolls and fees for the use of roads and motorways.

In general, the purpose of road tax is to levy charges on the use of roads and motorways by motor vehicles in the territory of the Czech Republic. However, this basic proposition is limited to such vehicles, which are used or intended for commercial purposes of a business entity. The road tax is regulated by Act No. 16/1993 Coll. on Road Tax, as amended by 19 amendments (hereinafter referred to as "ART"), whereby the legislators attempted to resolve the pressing problem of obtaining funds for the maintenance and development of road infrastructure in the Czech Republic. However, it is evident that the revenue of CZK 5.206 million (for 2012) is insufficient to meet this goal. There is a possible reserve in the receipts of road tax, apparent in the definition of the subject of the tax. Under Section 2 ART, the subject of the tax is road motor vehicles and their trailers if operated and registered in the territory of the Czech Republic and if used for business or self-employment or in direct connection therewith. The reserve in tax receipts can be seen, given the growing number of registered passenger vehicles, in the limitation of the scope of tax, particularly for passenger vehicles, only to vehicles used for business (Andrlík, 2013a). The introduction of taxation of all vehicles regardless of the criterion of business use would lead to an increase in revenues of public budget, more precisely of the State Fund of Transport Infrastructure, which is the beneficiary of gross revenue of this tax, according to Section 5 Act No. 243/2000 Coll. on Budgetary Determination of Taxes, as amended.

Operation of motor vehicles significantly affects everyone's life, both in the positive and negative ways. It undoubtedly increases the standard of living of the population and contributes to the economic development of the respective market economies. At the same time, it produces a wide range of environmental pollutants, the largest component being carbon dioxide (CO2) emissions, one of the negative externalities of road motor transport. Thus, motor transport is the significant producer of $\mathrm{CO} 2$ emissions, attributed a serious impact on global warming. As reported by the Ministry of Transport (2011), this sector is responsible for $15 \%$ of all $\mathrm{CO} 2$ emissions in the Czech Republic. Other negative aspects identified in connection with traffic include traffic congestions, noise, local pollution and climatic changes, which are typical problematic 
externalities requiring remedial measures adopted by the state. In general it applies that the older the motor vehicle used in road traffic is, the more harmful emissions it produces. Impact of the age of the fleet on the environment was historically proved by a number of expert studies. The most recent study on this topic, evidencing the direct proportion between the age of the vehicle and the volume of produced harmful substances polluting the atmosphere and as a result the entire environment, is the study entitled "The influence of vehicle fleet on environment", published by SDA-CIA on 27 March 2012, written by Ing. František Horák, CSc. According to SDA-CIA (2012), burning of hydrocarbon fuels generates two basic types of harmful emissions:

- Directly limited substances - carbon monoxide, hydrocarbon, and nitrogen oxides; CI engine produce substances such as carbon black and liquid components, which cling to dust in the air. These components are restricted by the regulation EHK R15 of 1971 and EC directives, and their limits are gradually tightened to reduce the levels of the above mentioned emissions. The limits are widely known as EURO 1 and higher.

- Indirectly limited substances - carbon dioxide (CO2) and sulphur oxides.

It is therefore important that the Czech Republic becomes involved in programmes and systems designed to improve the existing state of affairs and create a tax tool motivating consumers to replace their old cars with new ones which are more environmentally friendly, and thus to help mitigate negative impacts of traffic. Despite all the unfavourable statistics on the current condition of its vehicle fleet, the Czech Republic does not have any tax tool for motivating its citizens to improve the existing situation. From the theoretical standpoint, the ideal tool for elimination of negative externalities resulting from traffic is the so-called Pigovian tax. This is a remedial tax, whose main benefit is the possibility of imposing on the negative externality generator in the amount of the costs borne by the society, which would not be taken into account were it not for this intervention (Polluter Pays Principle). However, the main drawback of this idea is that in order to realize this theoretical concept, it is necessary to appraise in money all negative externalities generated by motor vehicles, which is a difficult and costly, if not impossible, process. For this reason the fiscal measures in road traffic use imperfect 
tools, which may be summarized to excise tax levied on fuels, registration charge and regular annual road tax.

The main goal of this contribution is to provide a description and analysis of the existing system of taxation of heavy-duty motor vehicle traffic in the form of road tax in the Czech Republic and selected European Union member states which integrated the environmental aspect to their road tax systems in order to reduce harmful emissions released into the atmosphere. Based on the results of the description and analysis, we shall further discuss options for integrating the environmental aspect into the system of taxation of trucks registered in the territory of the Czech Republic. Another aim of this contribution is to ponder the fact that introduction of taxes on road motor vehicles based on the production of harmful substances is a right step leading to the reduction of impacts of this negative externality caused by operation of motor vehicles. In order to reach the goals, it is necessary to study a range of specialized sources, in particular legal standards covering the topic. All the sources used in this article are listed in the bibliography section. The basic source data concerning the road tax system in the Czech Republic were obtained from Act No. 16/1993 on Road Tax, as amended by subsequent regulations. Source data for the European Union countries were taken from documents prepared by the European Commission and European Automobile Manufactures Association (ACEA).

\section{Taxation of trucks in the Czech Republic}

Levy of road tax in the Czech tax system in the form as we know today dates back to the origination of the new tax system embedded in Act No. 212/1992 Coll. on Tax System, which came into force on 1 January 1993. This tax model corresponds to tax systems of western market economies in terms of conception and structure, and is based on the classification of taxes as direct and indirect. However, the taxation of motor vehicles should correspond with requirements whose fulfilment is assumed by the tax levy. Široký (2008) sums up basic characteristics of a good tax system and respective taxes according to four basic principles - effectiveness, administrative simplicity, flexibility and fairness, while effectiveness and fairness are given priority. Andrlík (2012a) deals with these theoretically defined requirements applicable also to road tax, namely with effectiveness of road tax collection in the 
Czech Republic, measuring the direct administrative costs by means of the FTE method.

The subject of road tax is defined in Section 2 ART. The subject of the tax is road motor vehicles and their trailers if operated and registered in the territory of the Czech Republic and if used for business or self-employment or in direct connection therewith. As far as trucks are concerned, they are subject to road tax if their maximum permitted weight exceeds 3.5t, their purpose is solely transportation of load and are registered in the Czech Republic, regardless whether they are used for commercial purposes or not. Special vehicles manufactured for a different purpose, which use road infrastructures only exceptionally, are not subject to road tax under Section 2 par. 2 ART. Such vehicles include agricultural and forestry tractors including their trailers and special tracked vehicles and mobile working machines. These are vehicles whose primary purpose is working operations and which are not designed to travel along public roads.

For the determination of the tax base under Section 5 ART it is necessary to consider data from the registration book of the vehicle - the maximum permitted weight (in tons) and the number of axles, or the sum of maximum permitted weights per axle (expressed in tons) and the number of axles. The rate of road tax under Section 6 ART is based on the properties of the truck listed above. The tax rate may be reduced according to the date of the first registration of the motor vehicle. The reduction of the basic tax rate is based on a 36-month cycle, where after the first 36 months the basic tax rate is reduced by $48 \%$, after another 36 months by $40 \%$, and for the next 36 months the reduction amounts to $25 \%$. This provision of ART can be considered a certain form of motivation for road taxpayers to regularly renew their fleet and thus to acquire vehicles that are more environmentally friendly. At present, annual tax rates according to the above mentioned truck properties range from CZK 1,800 to CZK 50,400. The road tax is assessed on an annual basis and the tax period is equivalent to the calendar year. Under Section 15 ART, the taxpayer is obliged to file the tax return by 31 January after the tax period has ended. Section 3 of the Act on Road Tax regulates special-purpose vehicles, which are exempt from tax.

The relief on road tax defined in Section 12 ART may be seen as a current environmental aspect. The aim of the tax relief is to motivate taxpayers to mitigate negative impacts on the environment caused by the 
growing volume of road freight transport. The relief for truck depends on the number of travels by one vehicle in the course of the tax period, if it meets the conditions strictly prescribed by the law. A travel using combined transport under Section 12 par. 1 ART is deemed a shipment of goods in one and the same freight unit or a truck, trailer, semi-trailer with or without the towing vehicle, which uses also railway or inland waterway transport in case the segment carried by railway or waterway exceeds the direct line of 100 kilometres, and if the initial or final segment consists of transportation by road. A similar system of tax reliefs for combined transport is also used in France and the relief in such manner of transportation reaches $75 \%$. The concrete amounts of tax relief for combined transport in the Czech Republic are shown in Tab. 1.

\section{Tab. 1: Reliefs on road tax for combined transport in the Czech Republic}

\begin{tabular}{|c|c|}
\hline $\begin{array}{c}\text { Number of travels in the tax } \\
\text { period }\end{array}$ & Amount of tax relief in \% \\
\hline more than 120 travels & $90 \%$ \\
\hline from 91 to 120 travels & $75 \%$ \\
\hline from 61 to 90 travels & $50 \%$ \\
\hline from 31 to 60 travels & $25 \%$ \\
\hline
\end{tabular}

Source: Act No. 16/1993 Coll., on Road Tax, as amended by subsequent regulations.

However, this feature is not widely used by taxpayers, one of the reasons being the more complicated logistics and bigger time demands. As a result, the transportation of loads itself takes more time, a fact not often tolerated by customers. The taxpayers will, quite logically, conclude that the tax relief in view of annual expenses does not mean a significant saving especially in proportion to the difficult administration of combined transport and lost profit caused by the extended time periods.

In the present concept of the Czech Act on Road Tax, the environmental aspect of negative externalities consisting in the production of harmful substances released into the atmosphere by the operation of trucks is not taken into account, with the two above exceptions. Moreover, we can doubt the benefits of tax relief related to the combined transport. It is apparent that the current form of the Act 
Andrlík, B.: Road Tax on Truck Traffic with Environmental Aspects.

on Road Tax provides insufficient regulation for the elimination of harmful impacts of road freight traffic. A suitable tool to this end may be taxing trucks by road tax or registration tax based on more precise and measurable environmental aspects.

\section{Summary of environmental aspects in the European Union}

To ensure that road tax fulfils environmental goals, it is necessary to define its basic mechanism in such manner that it encourages purchase of environmentally friendly trucks. In many European Union countries, the calculation of road tax is still based on certain attributes of the vehicle, such as engine capacity or weight. Those member states, which introduced environmental aspects into their tax systems, are often criticized for their tax rates being too low to encourage the modernization of fleets. For this reason, the introduction of road tax based on the goal to reduce average emission levels of the fleet could be successful and could speed up the whole process of the fleet renewal in EU member states.

Another aim of this contribution, mentioned in "Introduction and Goal", is to ponder the fact that introduction of taxes on road motor vehicles based on the production of harmful substances is a right step leading to the reduction of impacts of this negative externality caused by operation of motor vehicles. Introducing taxation systems using an environmentally measurable aspect based on $\mathrm{CO} 2$ emissions has provable results with passenger motor vehicles in countries where this system has already existed for some time. According to Low Carbon Vehicle Partnership (2012), in Great Britain the number of vehicles with low levels of CO2 emissions doubled in 2010 compared with 2009, reaching more than 57 thousand. This is the case of the lowest road tax rates for vehicles with $\mathrm{CO} 2$ emission levels less than $100 \mathrm{~g} / \mathrm{km}$. Also, average $\mathrm{CO} 2$ emission levels in new passenger cars registered in 2010 dropped to $144.2 \mathrm{~g} / \mathrm{km}$, which is a $4 \%$ reduction compared with 2009. These numbers prove that the trend of reducing average levels of emissions in newly registered motor vehicles successfully continues. Fig. 1 shows the development of reducing average levels of $\mathrm{CO} 2$ emissions in Great Britain, evidencing long-term provability of the trend of reducing average emission levels since 1997. 


\section{Fig. 1: Development of average levels of $\mathrm{CO} 2$ emissions from new} passenger cars registered in Great Britain

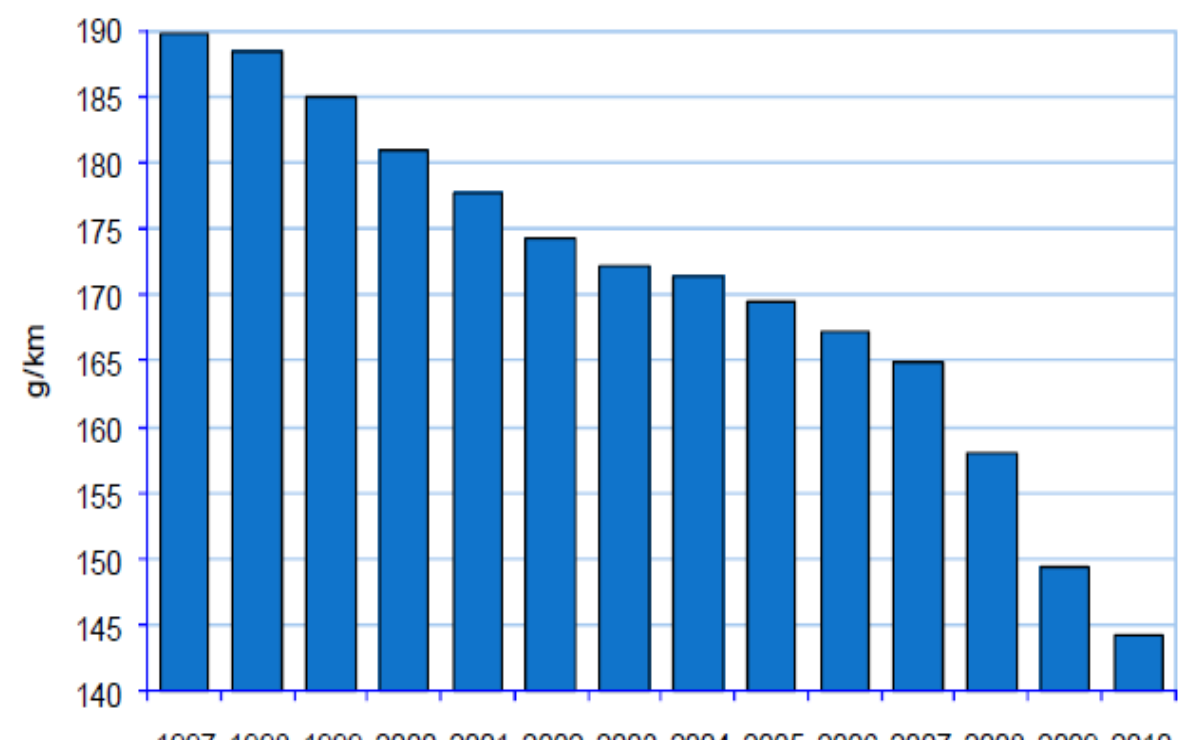

19971998199920002001200220032004200520062007200820092010

Source: Murray (2011).

According to Murray (2011) the Great Britain concerning passenger cars clearly confirms that the introduction of the environmental aspect to the concept of road tax has a positive effect leading to the reduction of harmful substances generated by the operation of motor vehicles. The detailed analysis of the systems of taxation of trucks in the European Union member states has identified that all member states impose road taxes on trucks, typically using the combination of weight and number of axles or suspension of axles. The overview of manners of tax base determination concerning trucks in EU member states is provided in Tab. 2. 
Andrlík, B.: Road Tax on Truck Traffic with Environmental Aspects.

Tab. 2: Determination of road tax base in EU member states

\begin{tabular}{|c|c|c|c|}
\hline Country & Road tax & Country & Road tax \\
\hline AUSTRIA & weight & ITALY & $\begin{array}{c}\text { weight, axles, } \\
\text { suspension }\end{array}$ \\
\hline BELGIUM & weight, axles & LITHUANIA & $\begin{array}{c}\text { weight, axles, } \\
\text { suspension }\end{array}$ \\
\hline BULGARIA & weight, axles & LUXEMBOURG & weight, axles \\
\hline CYPRUS & $\begin{array}{l}\text { weight, axles, } \\
\text { suspension }\end{array}$ & LATVIA & weight \\
\hline \begin{tabular}{|c|} 
CZECH \\
REPUBLIC \\
\end{tabular} & weight, axles & MALTA & $\begin{array}{c}\text { weight, axles, } \\
\text { suspension }\end{array}$ \\
\hline GERMANY & $\begin{array}{l}\text { weight, exhaust } \\
\text { emissions, noise }\end{array}$ & $\begin{array}{c}\text { THE } \\
\text { NETHERLANDS }\end{array}$ & weight \\
\hline DENMARK & $\begin{array}{l}\text { fuel consumption, } \\
\text { weight }\end{array}$ & POLAND & weight, axles \\
\hline ESTONIA & $\begin{array}{l}\text { weight, axles, } \\
\text { suspension }\end{array}$ & PORTUGAL & $\begin{array}{c}\text { weight, axles, } \\
\text { suspension }\end{array}$ \\
\hline SPAIN & payload & ROMANIA & weight, axles \\
\hline FINLAND & weight $\mathrm{x}$ days & SWEDEN & $\begin{array}{c}\text { weight, axles, } \\
\text { exhaust } \\
\text { emissions }\end{array}$ \\
\hline FRANCE & $\begin{array}{l}\text { weight, axles, } \\
\text { suspension }\end{array}$ & SLOVENIA & weight \\
\hline GREECE & weight & SLOVAKIA & weight, axles, \\
\hline HUNGARY & weight & $\begin{array}{c}\text { UNITED } \\
\text { KINGDOM }\end{array}$ & weight, axles \\
\hline IRELAND & weight & & \\
\hline
\end{tabular}

Source: ACEA (2013), own work.

It follows from Tab. 2 that all EU countries have road tax embedded in their tax systems and they assert it on an annual basis in order to comply with the respective components of the state budget. However, the environmental aspect forms a marginal issue or is not addressed at all. Further analysis shall focus on whether the environmental aspect is integrated into the system of road tax on trucks, either in the process of tax base determination, as mentioned in Tab. 2, or in the form of a 
relief from the assessed tax liability. The results of the analysis are summarized in Tab. 3, showing which EU countries apply the environmental aspect in the taxation of truck traffic.

Tab. 3: EU member states with the environmental aspect included in road tax

\begin{tabular}{|c|c|c|c|}
\hline Country & $\begin{array}{c}\text { Environmental } \\
\text { aspect }\end{array}$ & Country & $\begin{array}{c}\text { Environmental } \\
\text { aspect }\end{array}$ \\
\hline AUSTRIA & NO & ITALY & NO \\
\hline BELGIUM & NO & LITHUANIA & NO \\
\hline $\begin{array}{c}\text { BULGARI } \\
\text { A }\end{array}$ & YES & LUXEMBOURG & NO \\
\hline CYPRUS & NO & LATVIA & NO \\
\hline $\begin{array}{c}\text { CZECH } \\
\text { REPUBLIC }\end{array}$ & NO & MALTA & NO \\
\hline GERMANY & YES & THE & YES \\
\hline DENMARK & NO & POLAND & NO \\
\hline ESTONIA & NO & PORTUGAL & NO \\
\hline SPAIN & NO & ROMANIA & NO \\
\hline FINLAND & NO & SWEDEN & YES \\
\hline FRANCE & NO & SLOVENIA & YES \\
\hline GREECE & NO & SLOVAKIA & YES \\
\hline HUNGARY & YES & $\begin{array}{c}\text { UNITED } \\
\text { KINGDOM }\end{array}$ & NO \\
\hline IRELAND & NO & & \\
\hline
\end{tabular}

Source: ACEA (2013), own work.

The summary in Tab. 3 shows which EU member states use the environmental aspect as one of the criteria for the determination of road tax on trucks. It was ascertained that only 7 countries out of the $27 \mathrm{EU}$ member states apply this aspect in their tax systems, while the significance of the environmental aspect in the determination of the tax base is only marginal. Thus, the environmental problems of truck traffic are not dealt with, which is a different situation than with passenger cars. This statement is supported with detailed analysis of systems of taxation 
of passenger cars, using $\mathrm{CO} 2$ emission levels in the European Union countries, as mentioned by Andrlík (2012b). CO2 emission levels are applied in the determination of tax base in ten member states (Finland, Ireland, Cyprus, Luxembourg, the Netherlands, Germany, Portugal, Greece, Sweden and the United Kingdom). The most advanced system exists in Great Britain, which became a pioneer in introducing systems of taxation of passenger cars according to the production of $\mathrm{CO} 2$ emissions.

The most frequently used method of considering the environmental aspect in the case of trucks is application of EURO emission standards (EURO I, EURO II, EURO III, EURO IV and above). EURO emission standards set limits of exhaust emissions; higher EURO numbers imply stricter limits, requiring reduction of exhaust emissions. The standards restrict the volume of carbon monoxide (CO), hydrocarbons (HC), nitrogen oxides (NOx) and particulate matter (PM). The values are given in milligrams per kilometre. However, there are other substances generated by automobiles. Another example is carbon dioxide and sulphur compounds, which are not regulated by the standard. Carbon dioxide $(\mathrm{CO} 2)$ is not monitored in trucks at all, and in registration books only values for the determination of the applicable EURO standard are stated (numbers of the relevant directives, which the vehicle meets). This is a major difference in comparison with passenger cars, where the $\mathrm{CO} 2$ is the key quantity in determining the road tax base in ten member states of the European Union that have implemented the environmental reform in road taxes.

Countries, which take into account the type of EURO standard, met by a particular truck when calculating road taxes include Bulgaria, Hungary, the Netherlands, Germany, Slovakia, Slovenia and Sweden. The environmental aspect dependent on EURO emission standards is reflected in various surcharges or road tax reliefs in Bulgaria, Hungary, the Netherlands, Slovenia and Sweden. Bulgaria provides a $50 \%$ road tax relief for trucks complying with EURO II and higher emission standards. Payers of road tax in Hungary are provided a tax relief for trucks meeting EURO II emission standard in the amount of $20 \%$ and for trucks meeting EURO III and higher in the amount of $30 \%$. In the Netherlands, road tax is increased if the truck falls into EURO II category and lower. According to Verheid (2013), road tax is increased by:

- $90 \%$ for trucks complying with EURO 0 emission standard; 
- $\quad 75 \%$ for trucks complying with EURO I emission standard;

- $60 \%$ for trucks complying with EURO II emission standard.

Slovenia applies the system of reduction and increase of the assessed tax liability depending on whether the truck meets the particular emission standard. If the vehicle complies with EURO III emission standard, the assessed tax liability remains unchanged. Should the vehicle fail to meet the standard, the tax liability increases according to Uradni list (2013) as follows:

- EURO II by $5 \%$,

- EURO I by $20 \%$,

- EURO or lower $30 \%$.

If the vehicle complies with an emission standard higher than EURO III, the tax liability is decreased as follows:

- EURO IV by $12.5 \%$,

- $\quad$ EURO V by $25 \%$.

In Germany, the environmental element is included directly in the calculation of road tax. Tax rates for trucks depend on the weight of the vehicle, and the concrete rate is calculated according to compliance with requirements of pollution categories S1, S2, S3, S4, S5 and EEV (Enhanced Environmentally Friendly Vehicle). Another part of the calculation is the truck noise category G1. In comparison with the other mentioned countries, Germany has the most advanced way of applying the environmental aspect. In Sweden, the environmental aspect was introduced in road tax for trucks with weight over $3.5 \mathrm{t}$ on 1 October 2006. Heavy-duty vehicles over $3.5 \mathrm{t}$ and buses that meet EURO IV or higher emission standard have a lower tax liability on an annual basis. Truck that fails to meet minimally EURO IV pays road tax according to the original system, depending on the weight and axles. The system is continually modified and refined with the aim to privilege environmentally friendly trucks. 
For Romania, Tab. 3 shows that it does not take into account the environmental aspect in road tax. However, in order to protect the environment, Romania has introduced a special tax on pollution, a tax system quite unique within the European Union. The amount of the tax depends on the truck engine capacity and EURO emission group, which is met by the truck concerned. Tax rates are expressed in prices per $\mathrm{cm}^{3}$. Concrete rates of this tax are shown in Tab. 4.

\section{Tab. 4: Tax rates for vehicles of N1, N2, N3, M2, and M3 categories in Romania}

\begin{tabular}{|c|r|}
\hline Pollution standard & \multicolumn{2}{|c|}{ Tax EUR/cc } \\
\hline EURO 6 & 0.0 \\
\hline EURO 5 & 0.05 \\
\hline EURO 4 & 0.25 \\
\hline EURO 3 & 0.5 \\
\hline EURO 2 & 2.0 \\
\hline EURO 1 & 4.0 \\
\hline NON-EURO & 9.0 \\
\hline
\end{tabular}

Source: ACEA (2012), own work.

The last examined EU country, which applies the environmental aspect in road tax, is Slovakia. The specific feature of Slovak regulation is that road tax is governed by Act No. 582/2004 Coll. on Local Taxes and Fees on Communal Waste and Small Building Waste, as amended by subsequent legal regulations. The basis for the tax assessment for trucks is the total weight or the maximum permitted weight in tons and the number of axles. The tax rate under the above mentioned act might be determined by a generally binding regulation of a local administrative unit. This circumstance enabled introduction of the environmental aspect to road tax in certain regions in Slovakia. Five out of the seven regions introduced the application of EURO emission standards to road tax rates for trucks pursuant to the generally binding regulation of regional authorities. These 
are Nitra, Banská Bystrica, Trenčín, Trnava and Košice regions. Tax rates for trucks depend on the weight of the vehicle and the number of axles, but the amount of the tax is contingent on the compliance with the relevant EURO standard.

Tab. 5: Selected road tax rates for trucks in Košice Region

\begin{tabular}{|c|c|c|c|c|c|}
\hline \multirow{3}{*}{$\begin{array}{c}\text { Number of } \\
\text { axles }\end{array}$} & \multirow{2}{*}{\multicolumn{2}{|c|}{ Total weight in tons }} & \multicolumn{3}{|c|}{ Tax rate } \\
\hline & & & \multirow{2}{*}{$\begin{array}{c}\text { EURO } \\
\text { IV, V } \\
\text { EUR/year }\end{array}$} & \multirow{2}{*}{\begin{tabular}{|l} 
EURO III \\
EUR/year
\end{tabular}} & \multirow{2}{*}{$\begin{array}{c}\begin{array}{c}\text { other } \\
\text { vehicles }\end{array} \\
\text { EUR/year }\end{array}$} \\
\hline & From & to (incl.) & & & \\
\hline \multirow{4}{*}{1 or 2 axles } & & 1 & 63.07 & 66.22 & 69.38 \\
\hline & 1 & 2 & 112.86 & 118.50 & 124.15 \\
\hline & 2 & 4 & 189.21 & 198.67 & 208.13 \\
\hline & 4 & 6 & 285.47 & 299.74 & 314.02 \\
\hline & 6 & 8 & 375.09 & 393.84 & 412.60 \\
\hline & 8 & 10 & 471.35 & 494.92 & 518.49 \\
\hline & 10 & 12 & 564.30 & 592.52 & 620.73 \\
\hline & 12 & 14 & 707.03 & 742.38 & 777.73 \\
\hline & 14 & 16 & 849.76 & 892.25 & 934.74 \\
\hline & 16 & 18 & 992.5 & 1042.13 & 1091.75 \\
\hline & 18 & 20 & 1131.92 & 1188.52 & 1245.11 \\
\hline & $\ldots$ & $\ldots$ & $\ldots$ & $\ldots$ & $\ldots$ \\
\hline
\end{tabular}

Source: Varhaník (2013). 
Tab. 5 shows that compliance with EURO IV emission standard is a motivation element for taxpayers, which in case of a truck over 18 tons means a relief of 113.19 EUR per year if compared to a truck not meeting even EURO III standard. Trucks with a larger number of axles enjoy an even higher tax relief. The wording of regional decrees suggests an apparent effort to introduce the environmental aspect into the manner of determination of road tax in the Slovak Republic. Slovakia is the only country in the European Union, which established the environmental element directly to the mechanism of road tax determination, and from this perspective it is certainly the most advanced one. In the other EU countries described above the environmental element plays only a certain role of a bonus (or malus) to the tax liability assessed in advance, according to the relevant EURO standard.

Of the above mentioned systems of taxation of truck traffic with the environmental aspect, the Slovak system seems the most suitable for the Czech Republic in that it clearly links the environmental features to the tax determination and in this respect it has significant advantage over the other European Union countries. However, this system should be modified to apply for the entire territory of the Czech Republic without the discrimination between the regions, because different rules in different regions would increase administrative burden both on the level of state administration bodies and with respect to payers of road tax on trucks. This system of taxation is well applicable also to older trucks; the vehicle concerned either meets a certain EURO emission standard and is entitled to a preferential tax rate or it does not meet the standard and the taxpayer shall pay the highest rate.

\section{Conclusion}

Generally speaking, road tax, as we know it from the conditions of the Czech Republic, burdens users of roads and motorways, i.e. the entities operating road motor vehicles. The contribution deals with issues of introducing the environmental aspect to the system of collection of road tax for trucks. Taxation systems concerning road tax on trucks in the European Union countries are analysed. Within the framework of practical analysis of road tax systems in the European Union, detailed analysis is provided for those countries that have introduced a certain environmental feature to the process of road tax collection. Based on the analysis of truck taxation in the European Union, recommendations for 
the mechanisms of determination of road taxes related to the generation of polluting substances are made. If the state policy aims at the mitigation of negative externalities ensuing from motor traffic, it should maximally encourage incentives for emission reduction both on the part of producers and on the part of vehicle users.

In the systems of truck traffic taxation in EU member states we may find a number of common features particularly in the area of determination of the tax base using attributes such as vehicle weight and number of axles. What is a really marginal feature in the present road tax systems is the environmental aspect concerning trucks. We have identified only seven EU member states that use the environmental aspect in their systems of truck taxation, and it is usually limited to a bonus or a malus in case of compliance or non-compliance with an environmental standard. The environmental aspect is always represented by meeting the requirements of one of EURO emission standards, which follow from the relevant EEC/EC directives.

According to Andrlík (2013b) in 2011, 187200 trucks were registered in the Czech Republic. Of this number only 29462 trucks meet EURO V emission standard. The highest proportion is represented by trucks, which do not comply with any EURO emission standard (69 275 vehicles). This is the reason why the Czech Republic, within debates over green tax reform, should engage in an intense discussion over the change in the system of road tax imposed on trucks, due to the high production of harmful substances released into the atmosphere through the operation of old and environmentally non-compliant trucks. At the same time the Czech Republic should also fulfil its obligations following from the Kyoto Protocol, under which it committed itself to reducing greenhouse gas emissions.

Reform of the system of levy on truck traffic in the Czech Republic should, in my opinion, be based on the measures adopted by Slovakia and other European Union countries that have introduced the environmental aspect into their tax systems and committed themselves to fulfilling the obligations of the Kyoto Protocol, which among others strives to reduce greenhouse gas emissions generated by motor traffic. 
Andrlík, B.: Road Tax on Truck Traffic with Environmental Aspects.

\section{References}

ACEA (2012): Tax Guide 2012. [on-line], c2012, [cited $15^{\text {th }}$ January 2014], 〈http://bil.aipublish.no/ai_files/tax_guide_2012_124774.pdf〉.

ACEA (2013): Tax Guide 2013 - Highlights. [on-line], c2013, [cited 25 $5^{\text {th }}$ January 2014], <http://acea.be/uploads/publications/20130326 _TaxGuide2013Highlights.pdf $>$.

Andrlík, B. (2012a): Efficiency of road tax in the tax system of the Czech Republic. Acta Universitatis agriculturae et silviculturae Mendelianae Brunensis, 2012, vol. LX, no. 2, pp. 17-24.

Andrlík, B. (2012b): Taxation of passenger motor vehicles with enviromental aspect. Acta Universitatis Agriculturae et Silviculturae Mendelianae Brunensis, 2012, vol. LX, no. 7, pp. 9-18.

Andlík, B. (2013a): Collection of road tax in the years from 1993 - 2011 in the Czech Republic. Acta Universitatis Agriculturae et Silviculturae Mendelianae Brunensis, 2013, vol. LXI, no. 2, pp. 273-282.

Andlík, B. (2013b): Composition of motor vehicle fleet in the Czech Republic and the European Union. Acta Universitatis Agriculturae et Silviculturae Mendelianae Brunensis, 2013, vol. LXI, no. 7, pp. 19691976.

Boněk, V., at al. (2001): Lexikon - daňové pojmy. Ostrava, Sagit, 2001.

David, P. (2012): Principles of taxation of road motor vehicles and their possibilities of application. Acta Universitatis Agriculturae et Silviculturae Mendelianae Brunensis, 2012, vol. LX, no. 2, pp. 483-492.

Low Carborn Vehicle Partnership (2011): Number of low carbon cars sold in the UK doubled in 2010. [on-line], c2011, [cited $1^{\text {st }}$ February 2014], <http://www.lowcvp.org.uk/news,number-of-low-carbon-carssold-in-the-uknbspdoubled-in-2010_1613.htm>.

Ministerstvo dopravy (2011): Ročenka dopravy 2010. [on-line], c2011, [cited $3^{\text {rd }}$ March 2014], <https://www.sydos.cz/cs/rocenka2010/rocenka/htm_cz/index.html>.

Murray, J. (2011): Car CO2 taxationand it's impal on the British car fleet. [on-line], c2011, [cited $20^{\text {th }}$ January 2014], <http://www.lowcvp. org.uk/search/results.htm?q=murray\%20car\%20CO2>. 
SDA-CIA (2012): Znečišstování ovzduši provozem OA v ČR. [on-line], c2012, [cited $2^{\text {nd }}$ March 2014], <http://portal.sda-cia.cz/index.php? option=com_content\&task=view\&id=1841\&Itemid=125>.

Široký, J. at al (2008): Daňové teorie s praktickou aplikací. Praha, C. H. Beck, 2008.

Uradni list (2013): Uredbo o načinu določanja in višini letne dajatve za uporabo vozil $v$ cestnem prometu. [on-line], c2013, [cited $5^{\text {th }}$ March 2014], $<$ http://www.uradnilist.si/1/objava.jsp?urlid=2008100\&stevilka=4240>.

Varhaník, P. (2013): Všeobecně závazné nařizení Košického samosprávného kraja zo 6. Decembra 2010. [on-line], c2013, [cited $15^{\text {th }}$ March 2014], <http://pavolvarhanik.sk/sites/default/files/dmv-2012ke.pdf $>$.

Verheid.nl (2013): Wet op de motorrijtuigenbelasting 1994. [on-line], c2013, [cited 26 ${ }^{\text {th }}$ March 2014], <http://wetten.overheid. nl/BWBR0006324/geldigheidsdatum_13-07-2012>.

Zákon č. 212/1992 Sb., o soustavě daní.

Zákon č. 16/1993 Sb., o dani silniční, v platném znění.

Zákon č. 243/2000 Sb., o rozpočtovém určení daní, v platném znění. 


\title{
Road Tax on Truck Traffic with Environmental Aspects
}

\begin{abstract}
The contribution deals with issues of taxation of truck traffic in the Czech Republic and European Union countries. The article discusses the current need for the introduction of environmental features aiming at the mitigation of harmful substances emitted into the atmosphere to the system of truck traffic taxation. Within the tax system, we focus on the road tax mechanism, defining only those circumstances that relate to environmental features of the determination of the tax base or tax reliefs dependent on the compliance with the applicable EURO emission standard. The article outlines systems of truck taxation in the European Union member states with focus on the determination of the tax base. The EURO emission standard, which is clearly identified and binding upon all the truck producers at present, has been introduced as the environmental factor related to pollutants emitted to the atmosphere, and it subsequently assumes the role of a "green" feature of the road taxes on trucks in those EU countries which introduced such environmentally friendly aspects. A special section describes systems of road tax with environmental aspects levied on trucks in Bulgaria, Hungary, the Netherlands, Germany, Slovak Republic, Slovenia and Sweden. In conclusion, we mention the necessity of discussion over this topic in the conditions of the Czech Republic and the requirement to regulate the system of road taxes imposed on trucks, calling for reduction of harmful substances generated by traffic.
\end{abstract}

Key words: EURO standard; Negative externality; Road tax.

JEL classification: $\mathrm{H} 21, \mathrm{H} 23$ 